\title{
EFFECTIVE PARAMETERS IN TERACTION STUDY FOR CERIUM EXTRACTION FROM SULFURIC MEDIA USING DI-(2-ETHYLHEXYL) PHOSPHORIC ACID
}

\author{
Eslam Kashi, ${ }^{1}$, Razieh Habibpour ${ }^{1}$, Armin Maleki ${ }^{1}$, Hesamoddin Gorzin ${ }^{2}$
}

https://doi.org/10.23939/chcht11.02.144

\begin{abstract}
The solvent extraction of cerium(III) from its sulfuric solution with di-(2-ethylhexyl) phosphoric acid diluted by kerosene was investigated. Initially, a survey was conducted in order to identify the conditions influencing the solvent extraction process. Extractant concentration in the organic phase, organic phase to aqueous phase ratio, temperature, $\mathrm{pH}$, and contact time were identified as important factors. Among these factors, the temperature and contact time were found less effective in comparison to other factors. Thus, a contact time of ten minutes for the two phases at room temperature of $298 \mathrm{~K}$ was chosen for all experiments. Design expert software was employed for designing the experiments, investigating the effects of the factors on the solvent extraction, statistical analysis, and obtaining the optimal values of the factors. It was established that the factors influencing the solvent extraction, except extractant concentration and organic phase to aqueous phase ratio, were independent and have no interaction on each other.
\end{abstract}

Keywords: cerium, design of experiments, di-(2ethylhexyl) phosphoric acid, solvent extraction.

\section{Introduction}

The expression "Rare Earth Elements" refers to a group of 17 elements that include scandium, yttrium, and lanthanides, which share similar chemical characteristics. However, the naming of this group is not very suitable because most of these elements are commonly found in the earth's crust, albeit in a scattered and random manner and within very few, high grade minerals that can be economically mined $[1,2]$.

\footnotetext{
${ }^{1}$ Department of Chemical Technologies, Iranian Research Organization for Science and Technology

P.O. Box 33535111, Tehran, Iran

${ }^{2}$ Chemical Engineering Department, School of Engineering,

Islamic Azad University - Tehran North Branch, Tehran, Iran.

Kashi@irost.ir

(c) Kashi E., Habibpour R., Maleki A., Gorzin H., 2017.
}

Based on the growing demand for the pure form of these elements in international markets, mining and separating these elements have attracted significant attention. The application of these elements can be generally categorized into five groups: chemical, metallurgical, optical, magnetic, and atomic [2, 3].

Cerium is the most common amongst the rare earth elements. From the list of 83 elements found naturally in the earth's lithosphere, cerium is the $28^{\text {th }}$ in abundance.

Cerium has two ionic forms, cerous $\mathrm{Ce}^{3+}$ and ceric $\mathrm{Ce}^{4+}$, which make this element popular in several industries for various purposes. The ceric ion is a powerful oxidant and its most commonly used form is $\mathrm{CeO}_{2}$ [4] .

The separation of rare earth elements is generally achieved through solvent extraction. This method is most popular due to the fact that it is easier to control the great amount of charged liquids involved and the speed of the processes; it's also easy and practical for the extraction of rare elements [5].

For a solvent extraction of rare earth elements, aside from the organic phase diluent, a special variation of organic extractant is used. These extractants are based on organic phosphorous acids such as di-2-ethylhexylphosphoricacid (D2EHPA), 2-ethylhexylphosphonic acid mono-2-ethylhexyl ester (HEHEHP), and tri- $n$-butylphosphate (TBP). In addition, tri- $n$-octylphosphine oxide (TOPO), derivations of carboxyl acid, amines, ketones, etc. can also be used in such extractions [1, 4, 6-8].

Abhilash et al. [9] conducted several experiments using a sulfuric acidic medium in order to extract lanthanum and cerium from Indian red mud. The experiments conducted were initiated by the acidic leaching of the red mud followed by the liquid-liquid extraction with various kinds of extractants in order to determine the possibility of the separation and extraction of the mentioned elements. The results revealed that in comparison to extractants such as DEHPA and cyanex 272, cyanex 301 has more potential in the complete extraction of cerium, lanthanum, and scandium.

Wuping et al. [10] analyzed and studied the solvent extraction of $\mathrm{Ce}(\mathrm{IV})$ and fluorine from the simulated 
sulfuric acid leaching of bastnasite. They utilized cyanex 923 as the extractant. They also added the boric acid to the solution in order to form chelate with fluorine. The results showed that the boric acid can enhance the extraction of hydrofluoric acid, but it can't be extracted alone by cyanex 923. Another outcome of their research was that the temperature does not affect the process of cerium extraction [10].

Zhang et al. [11] studied the extraction of Ce(IV) using bifunctional ionic liquid as the extractant from sulfuric solutions. In this research, $n$-heptane was used as the diluent. In addition, they studied the effect of the salting-out agent, concentration of sulfuric acid, and concentration of extractant. By examining the thermodynamic parameters, this process was found to be exothermic. The extraction order in the study was as follows: $\mathrm{Ce}(\mathrm{IV})>\mathrm{Th}(\mathrm{IV})>\mathrm{Ce}(\mathrm{III})$.

Lu Jun et al. [12] studied the solvent extraction of $\mathrm{Ce}(\mathrm{IV})$ and $\mathrm{Th}(\mathrm{IV})$ from the sulfuric acid solution using cyanex 923 diluted in $n$-heptane. The relationship between extraction and temperature and acidity were investigated. The stripping characteristics of $\mathrm{Ce}(\mathrm{IV})$ and $\mathrm{Th}(\mathrm{IV})$ from the organic solution were also studied. The results revealed that the acidity of the aqueous solution had no effect on the extraction of $\mathrm{Ce}(\mathrm{IV})$, but it increased the extraction of Th(IV); the stripping of Ce(IV) from the organic solution also increased in direct relation with the increase of the sulfuric acid concentration [12].

In this research, the effect of $\mathrm{pH}$ factor, concentration of extractant, and the ratio of organic to aqueous phase on the solvent extraction of cerium was investigated. A review of the existing literature in this matter reveals that the factors affecting solvent extraction have been considered as independent of one another and were studied separately. Therefore, in this study, the factors affecting the solvent extraction of cerium were studied in a manner in which the relationships between the factors are taken into consideration as well. To that effect, experiment designing software, namely "Design Expert", has been used to design the experiments and analyze the results of the said experiments.

\section{Experimental}

There are many factors that affect the solvent extraction. The most important of these factors, which have been identified by means of numerous researches, are as follows:

- type of extractant

- type of diluent

- concentration of extractant

- $\mathrm{pH}$ of solutions

- volume ratio of phases

- extraction temperature
- contact time between the two phases

The review of similar studies [6, 10-13] reveals that among the abovementioned factors, time and temperature have had the least effects; therefore, based on the preceding studies, the optimal amount of both was chosen. Among the extractants, D2EHPA was selected because it is more effective and has also shown the highest extraction percentage for cerium when compared to other extractants. In the solvent extraction of rare earth elements, various kinds of diluents are used in order to dilute the organic extractant. In this study, kerosene was used because it is commonplace, non-toxic, non-volatile, and inexpensive in comparison with other diluents. For determining the extent of the effect of the three remaining factors and based on preceding studies, intervals were assigned and these intervals were used for designing the experiments by software. Table 1 shows the assigned intervals.

In previously conducted works, in order to assess the effects of these three factors on the extraction of cerium, each one was considered independently. This created a problem in the sense that the interaction between the factors was ignored and the factors were considered separate by one another; therefore, the optimum values for each factor was not reliable. Hence, this study designed the experiments in a way that the potential interaction between the factors could be studied as well.

The full factorial design of the factors is a method that is generally used to determine all the possible existing formations between the factors; it is the most reliable method. However, a very important limitation of this method is the number of experiments required, which is both expensive and time consuming.

Today, Response Surface Method (RSM) is used in order to design experiments; RSM is generated through statistical software such as "Design Expert" and "MINITAB". This method not only reduces the amount of experiments conducted, but also decreases the need to repeat experiments in order to calculate errors which enables the study of potential interactions between the factors as well. Table 2 compares the different methods of experiment design for three factors in five levels.

Taking into account $\mathrm{pH}$, three factors of extractant concentration, and phase ratio, the appropriate intervals were assigned and integrated into the experimental designs by "Design Expert" software.

In the designing of these experiments, a response surface method (RSM) and central composite design (CCD) were used. Twenty experiments were designed by "Design Expert" software. Upon completion of each experiment, the results which included the extraction percentage and distribution ratio were calculated. Table 3 shows the conditions and results of these 20 experiments. 
Table 1

Values and intervals assigned to factors affecting the solvent extraction of cerium

\begin{tabular}{|l|c|}
\hline \multicolumn{1}{|c|}{ Factors affecting the solvent extraction } & Interval or value \\
\hline Temperature, $\mathrm{K}$ & 298 \\
\hline Contact time, min & 10 \\
\hline Extractant concentration, mol & $0.01-0.1$ \\
\hline Initial pH pf aqueous solution & $1-6$ \\
\hline Ratio of organic phase to aqueous phase & $0.25-3$ \\
\hline
\end{tabular}

Table 2

Various methods of experiment design for 3 factors in 5 levels

\begin{tabular}{|l|c|c|c|}
\hline $\begin{array}{c}\text { The schematic of the number } \\
\text { of experiments }\end{array}$ & $\begin{array}{c}\text { Number of experiments } \\
\text { (with repeat) }\end{array}$ & $\begin{array}{c}\text { Number of experiments } \\
\text { (without repeat) }\end{array}$ & $\begin{array}{c}\text { Method } \\
\text { of experimental design }\end{array}$ \\
\hline
\end{tabular}

Table 3

Designed experiments by "Design Expert" software and their results

\begin{tabular}{|c|c|c|c|c|c|c|}
\hline $\begin{array}{c}\text { Number of } \\
\text { experiment }\end{array}$ & Type of point & $\begin{array}{c}\text { D2EHPA } \\
\text { Concentration }\end{array}$ & Phase ratio & $\mathrm{pH}$ & $\begin{array}{c}\text { Extraction } \\
\text { percentage }\end{array}$ & $\begin{array}{c}\text { Distribution } \\
\text { coefficient }\end{array}$ \\
\hline 1 & Axial & 0.1 & 1.62 & 3.5 & 99.89 & 565.789 \\
\hline 2 & Factorial & 0.03 & 2.44 & 2.0 & 84.6 & 2.25 \\
\hline 3 & Center & 0.06 & 1.62 & 3.5 & 99.49 & 122.51 \\
\hline 4 & Factorial & 0.08 & 2.44 & 5.0 & 99.82 & 224.35 \\
\hline 5 & Factorial & 0.03 & 0.81 & 5.0 & 76.74 & 4.06 \\
\hline 6 & Axial & 0.06 & 1.62 & 1.0 & 43.18 & 0.47 \\
\hline 7 & Factorial & 0.08 & 0.81 & 2.0 & 96.33 & 32.3 \\
\hline 8 & Center & 0.06 & 1.62 & 3.5 & 91.32 & 6.5 \\
\hline 9 & Center & 0.06 & 1.62 & 3.5 & 93.79 & 9.32 \\
\hline 10 & Center & 0.06 & 1.62 & 3.5 & 93.03 & 8.23 \\
\hline 11 & Factorial & 0.03 & 0.81 & 2.0 & 60.94 & 1.92 \\
\hline 12 & Axial & 0.06 & 3.00 & 3.5 & 98.62 & 23.61 \\
\hline 13 & Axial & 0.01 & 1.62 & 3.5 & 42.53 & 0.46 \\
\hline 14 & Center & 0.06 & 1.62 & 3.5 & 95.03 & 11.8 \\
\hline 15 & Axial & 0.06 & 0.25 & 3.5 & 55.95 & 5.08 \\
\hline 16 & Factorial & 0.08 & 2.44 & 2.0 & 98.6 & 28.91 \\
\hline 17 & Axial & 0.06 & 1.62 & 6.0 & 98.9 & 55.76 \\
\hline 18 & Center & 0.06 & 1.62 & 3.5 & 93.88 & 9.46 \\
\hline 19 & Factorial & 0.03 & 2.44 & 5.0 & 98.99 & 40.04 \\
\hline 20 & Factorial & 0.08 & 0.81 & 5.0 & 99.13 & 139.9 \\
\hline
\end{tabular}




\subsection{Chemicals}

All the chemicals and reagents used were of analytical reagent grade. Cerium nitrate was supplied by the "Merck" company and was used to make the aqueous solutions. Sulfuric acid and ammonium were used to adjust the acidity of aqueous solutions and were Merck products.

D2EHPA was supplied by "Merck". This extractant was diluted in kerosene which was supplied by "Fluka". In all experiments laboratory distilled water was used to make the solutions.

The solutions were stirred by a magnet stir machine and the separation of the two phases was completed by a decantation funnel. The analyses of the aqueous solutions were performed by an inductively-coupled plasma atomic emission spectrometry (ICP-AES) or atomic spectroscopy.

\subsection{Experimental M ethods}

All samples for these experiments were synthesized. The desired concentration of each element in the aqueous solution was obtained by dissolving a certain amount of that element's salt in distilled water. The $\mathrm{pH}$ value of the aqueous solutions was adjusted by adding ammonium and sulfuric acid.

In this study, the aqueous and organic phases with prior designated volume ratios were poured into a $50 \mathrm{ml}$ beaker. In order to achieve equilibrium and solvent extraction, it was placed on a magnetic stirrer for $10 \mathrm{~min}$. All experiments were conducted at room temperature (298 K).

The transfer rate of metal ions from the aqueous phase to the organic phase is named as the distribution ratio $(D)$. In order to calculate the distribution ratio and extraction percentage, the following formulas are utilized:

$$
\begin{gathered}
D=\frac{\text { metal concentration in organic phase }}{\text { metal concentration in aqueous phase }} \\
E=\frac{D}{D+\left(V_{a} / V_{o}\right)} \cdot 100
\end{gathered}
$$

where $E$ - the extraction percentage, $D$ - the distribution ratio, $V_{a}$ and $V_{o}$ - the volume of aqueous and organic phase, respectively.

\section{Results and Discussion}

The experiment results (distribution ratio and extraction percentage) were statistically analyzed by "Design Expert" software, and the possible mathematical models were surveyed. Table 4 shows the mathematical models.
Surveyed mathematical models

\begin{tabular}{|c|c|c|}
\hline Model & The $p$-value & Lack of fit \\
\hline Linear & 0.0039 & 0.0679 \\
\hline 2FI & 0.7094 & 0.0583 \\
\hline Quadratic & 0.7127 & 0.0441 \\
\hline Cubic & 0.6746 & 0.0166 \\
\hline
\end{tabular}

Note: $* 2$ factor interaction

The $p$-value is the level of marginal significance within a statistical hypothesis test that represents the probability of the occurrence of a given event. The $p$-value is used as an alternative to rejection points to provide the smallest level of significance at which the null hypothesis would be rejected. The smaller the p-value, the stronger is the evidence in favor of the alternative hypothesis.

Lack of fit is a criterion to determine how correctly the chosen model represents the relations between laboratory factors and response variables. It will be mentioned when important terms such as terms of the quadratic model or terms regarding the interaction between the factors are missing from the models.

According to the user guide of the software, only those models are acceptable which have the $p$-value lower than 0.05 and their lack of fit is greater than 0.05. Based on these criteria and the offered models in Table 4, only the linear model can be acceptable.

Finally, the formula taken from the linear model to calculate the extraction percentage forms the entered factors as follows:

$$
\begin{aligned}
& \text { \%extraction }=-2.28327+861.4968 \text { D } 2 \text { EHPAconc. }+ \\
& +24.30182 \frac{\text { organic }}{\text { aqueous }}+6.30113 p H- \\
& -245.41605 \text { D } 2 \text { EHPAconc. } \cdot \frac{\text { organic }}{\text { aqueous }}
\end{aligned}
$$

Without considering the sign of regression model coefficients for variables and interactions, the order of effectiveness of all variables and their binary interactions is as follows (higher model coefficient in absolute values):

$$
\text { D2EHPAconc. }>\text { D2EHPAconc. } \frac{\text { organic }}{\text { aqueous }}>\frac{\text { organic }}{\text { aqueous }}>p H
$$

Table 5 shows the results of the second-order response surface in the form of analysis of variance (ANOVA); the results indicated that the equation adequately represented the actual relationship between the independent variables and the responses. The positive or negative sign of model coefficient values described the direction of each variable or interaction effect on the response, i.e., positive values variables' increment caused increases in extraction yields while negative values variables' increment caused a decrease in extraction yield. 


\section{Table 5}

Analysis of variance (ANOVA) for cerium extraction efficiency

\begin{tabular}{|l|c|}
\hline \multicolumn{1}{|c|}{ Parameter } & Value \\
\hline Std. Dev. & 14.05 \\
\hline Mean & 84.71 \\
\hline C.V. \% & 16.58 \\
\hline PRESS & 4546.61 \\
\hline R-Squared & 0.6295 \\
\hline Adj R-Squared & 0.5440 \\
\hline Pred R-Squared & 0.3434 \\
\hline Adeq Precision & 8.977 \\
\hline
\end{tabular}

Eq. (3) shows that three main factors (D2EHPA, organic to aqueous phase ratio, $\mathrm{pH}$ ) had positive signs and interaction between D2EHPA concentration and organic to aqueous phase ratio had a negative sign and a reverse effect on the responses.

The results suggested that the change of D2EHPA concentration, and organic to aqueous phase ration had very significant effects on the efficiency of cerium extraction.

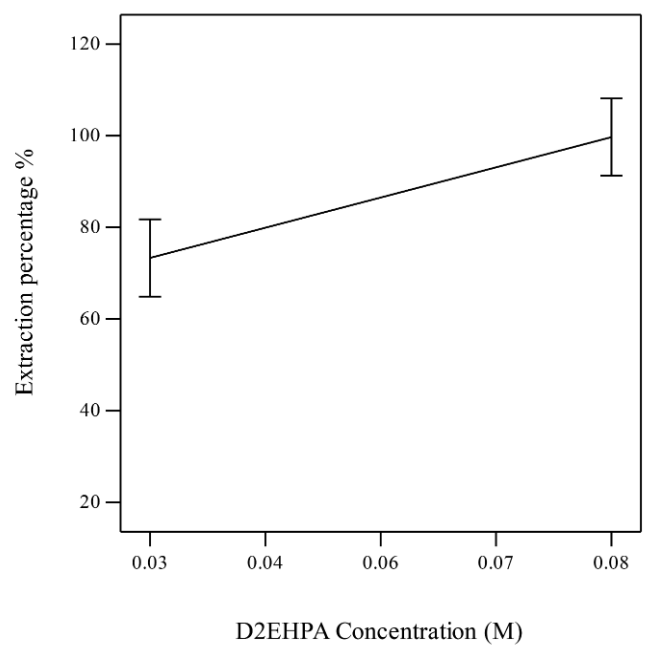

Fig. 1. Extraction behavior of cerium as a function of D2EHPA concentration when $\mathrm{pH}=4$ and $\mathrm{O} / \mathrm{A}=1.5$

\subsection{Effect of Extractant Concentration on Extraction Percentage}

Fig. 1 shows the changes in extraction percentage versus extractant concentration, where $\mathrm{pH}=4$ and the organic to aqueous phase ratio $(\mathrm{O} / \mathrm{A})$ is 1.5 .

By increasing the concentration of D2EHPA in the organic solution, the extraction percentage increases. In this form, the number of ligands increases in ratio to the number of metal ions in the solution. Therefore, more metal ions can be extracted from the aqueous solution.

\subsection{Effect of Phase Ratio on Extraction Percentage}

Fig. 2 shows the changes in extraction percentage versus changes in the ratio of organic to aqueous phase where $\mathrm{pH}=4$ and D2EHPA concentration is $0.05 \mathrm{~mol}$.

As seen in Fig. 2, by increasing the ratio of organic phase to the aqueous phase, the extraction percentage increases as well. By increasing this ratio, the amount of extractant that is in contact with cerium ions in the aqueous solution increases as well, and therefore the extraction percentage increases.

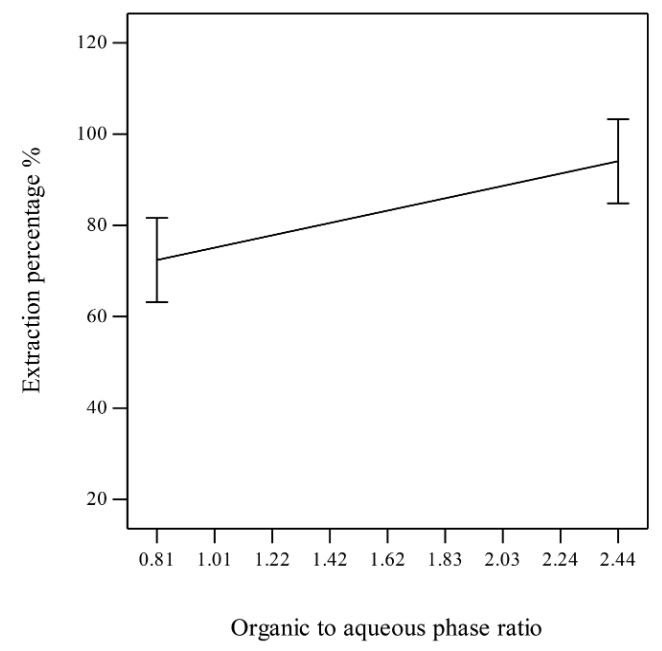

Fig. 2. Effect of phase ratio on extraction of cerium by DEHPA when $\mathrm{pH}=4$ and DEHPA concentration is $0.05 \mathrm{~mol}$

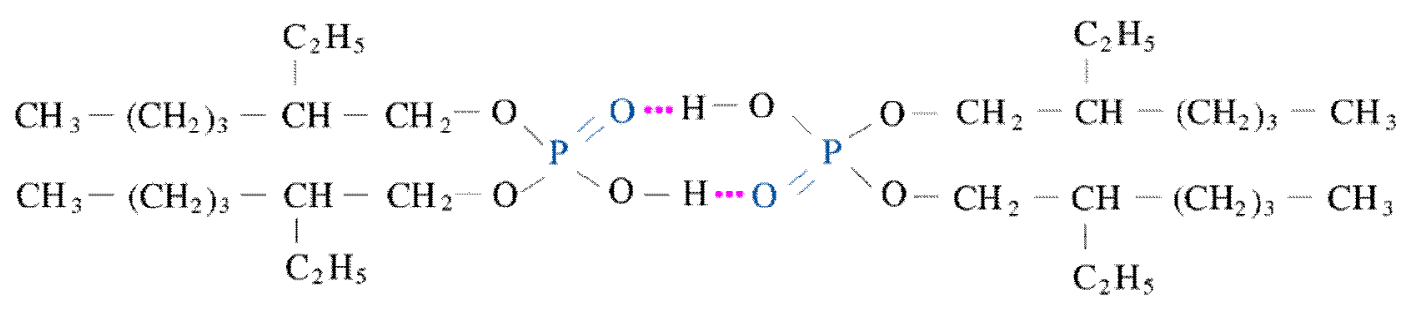

Fig. 3. Dimeric structure of D2EHPA [5] 


\subsection{Effect of pH on Extraction}

\section{Percentage}

The structure and mechanism of the extraction by D2EHPA is shown in Fig. 3 and Eq. (4).

$$
R E_{(a)}^{3+}+3 H_{2} A_{2(o)} \leftrightarrow R E A_{3} \cdot 3 H A_{(o)}+3 H_{(a)}^{+}
$$

Based on the fact that D2EHPA is a cationic extractant and in the extraction process with this particular extractant, $\mathrm{H}^{+}$is released (Eq. (4)) and thus by increasing $\mathrm{pH}$ of the solutions, the extraction percentage must increase as well.

Fig. 4 shows the changes in the extraction percentage versus the $\mathrm{pH}$ changes where DEHPA concentration is $0.05 \mathrm{~mol}$ and the $\mathrm{O} / \mathrm{A}$ ratio is 1.5 .

\subsection{Interaction between D2EH PA Concentration and Organic to Aqueous Phase Ratio}

Fig. 5 shows the interaction between D2EHPA concentration and organic to aqueous phase ratio for different $\mathrm{pH}$.

According to the graphs in Fig. 5, it is understood that the D2EHPA concentration and organic to aqueous

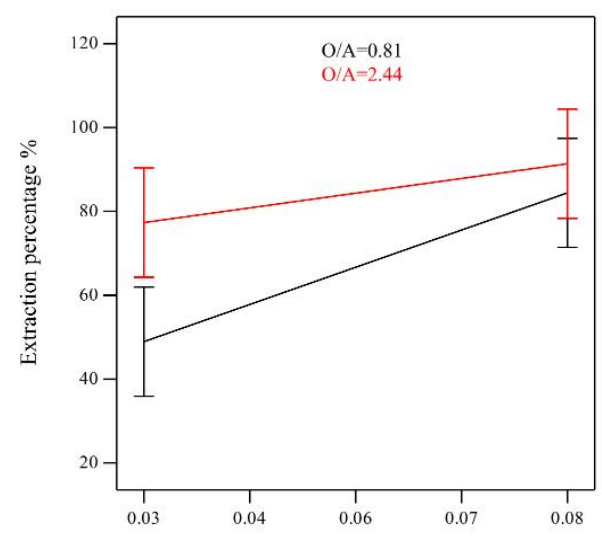

a. $\left(\mathrm{pH}^{-2}\right)$

D2EHPA Concentration (M)

Fig. 5. Interaction between D2EHPA concentration and organic to aqueous phase ratio phase ratio have interaction for all three different $\mathrm{pH}$ values. At the lower ratio of the organic to aqueous phase (0.81), the extraction increases with the increase in the extractant concentration. This extraction increase is slower at the higher O/A ratio (2.44), which reveals that the effect of the extractant concentration is lower at higher ratio of the organic to aqueous phase.

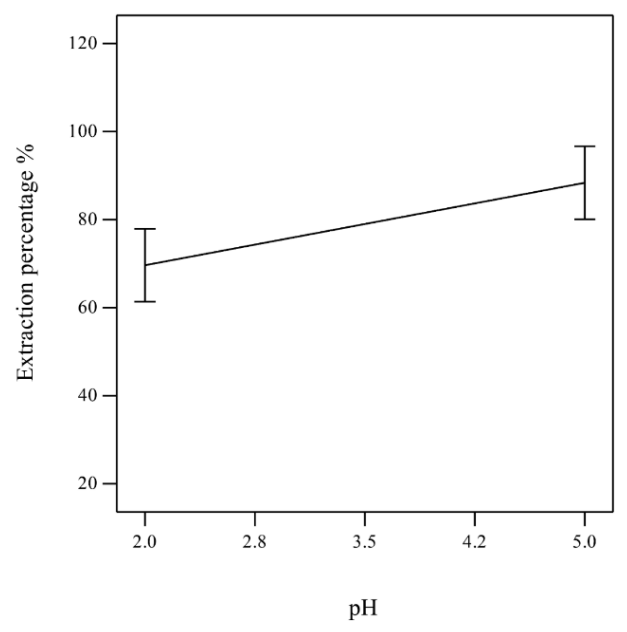

Fig. 4. Effect of $\mathrm{pH}$ on extraction of cerium by DEHPA; DEHPA concentration is $0.05 \mathrm{~mol}, \mathrm{O} / \mathrm{A}$ ratio is 1.5

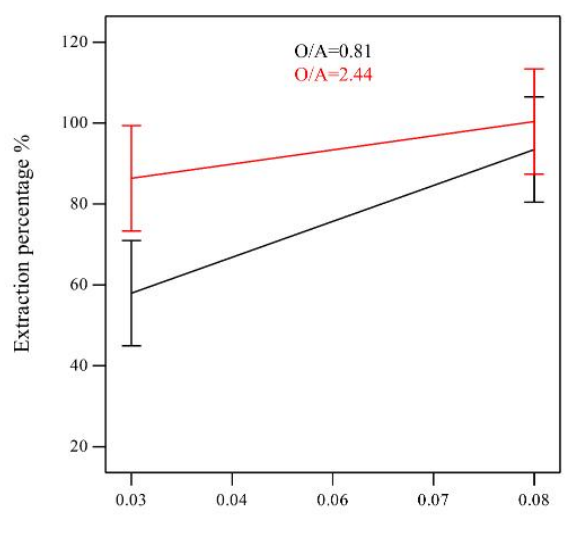

b. $(\mathrm{pH}=3.5)$

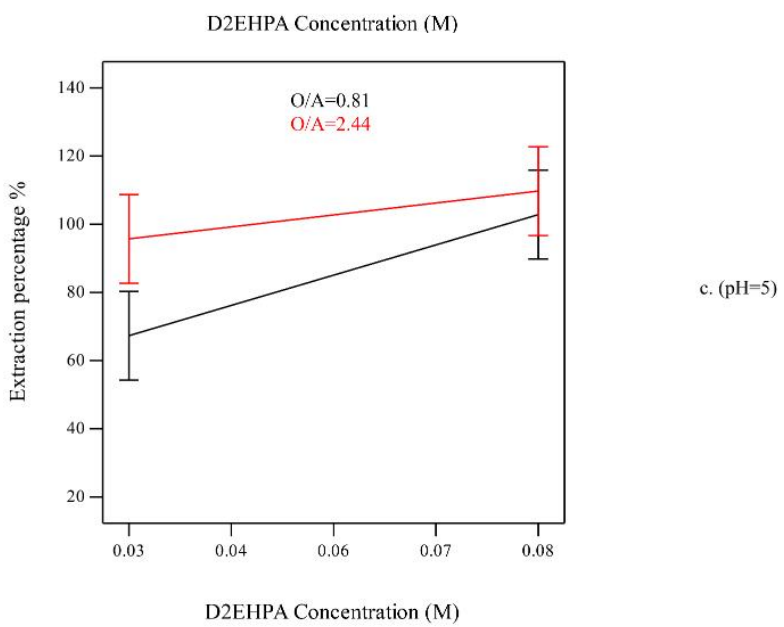



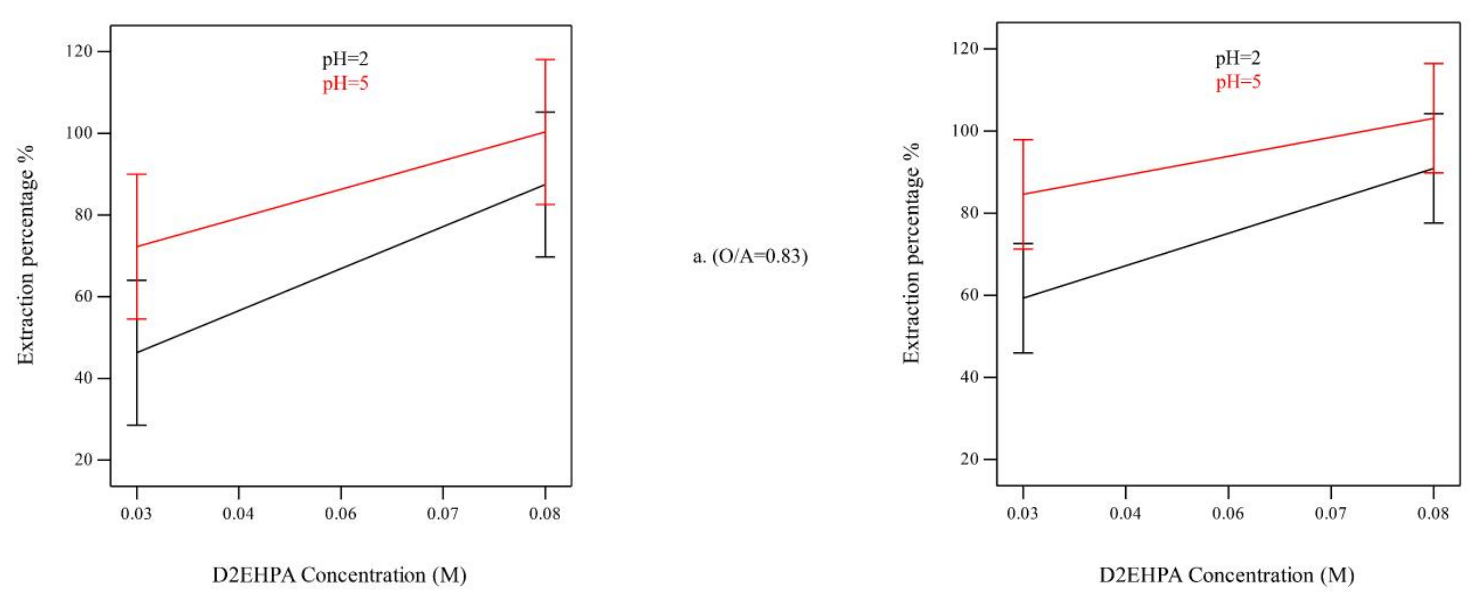

b. $(\mathrm{O} / \mathrm{A}=1.6)$

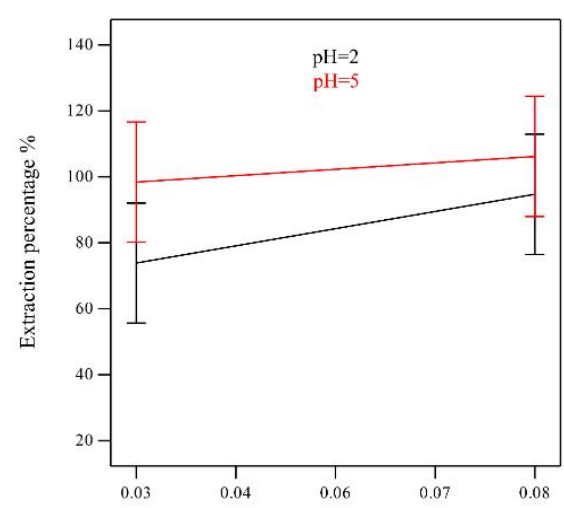

c. $(\mathrm{O} / \mathrm{A}=2.44)$

Fig. 6. Interaction between D2EHPA concentration and $\mathrm{pH}$
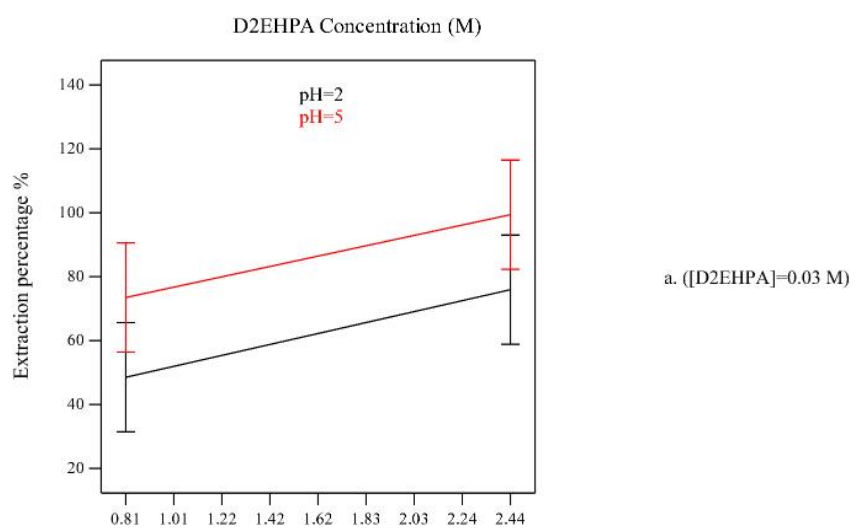

Organic to aqueous phase ratio

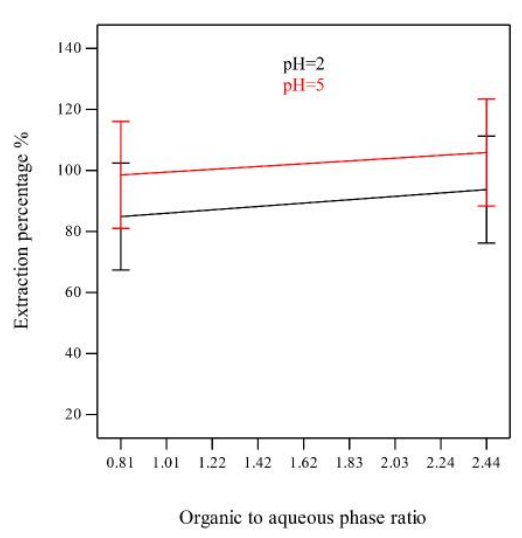

c. ([D2EHPA] $=0.08 \mathrm{M})$

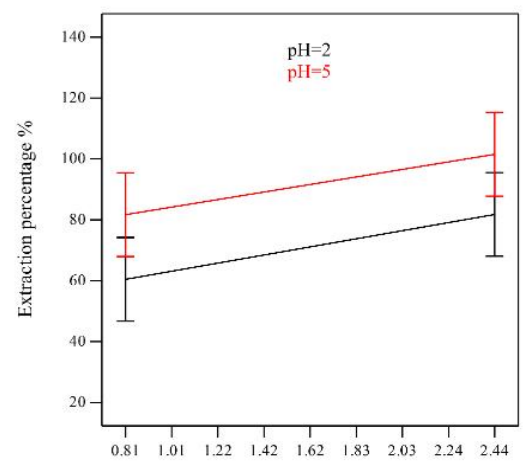

b. ([D2EHPA] $-0.05 \mathrm{M})$

Organic to aqueous phase ratio

Fig. 7. Interaction between organic to aqueous phase ratio and $\mathrm{Ph}$ 


\subsection{Interaction between D2EHPA Concentration and $\mathrm{pH}$}

Fig. 6 shows the interaction between D2EHPA concentration and $\mathrm{pH}$ at different ratios of organic to aqueous phase.

Based on the graphs in Fig. 6, it is understood that at high (5) and low (2) $\mathrm{pH}$ the extraction percentage also increases with an equal slope with the increase of D2EHPA concentration. Therefore, it can be said that these two factors do not have a significant interaction on each other.

\subsection{Interaction between Organic to Aqueous Phase Ratio and pH}

Fig. 7 shows some interactions between the organic to aqueous phase ratio and $\mathrm{pH}$ at different concentrations of D2EHPA extractant.

Based on the graphs in Fig. 7, it is understood that with the increase of the volume ratio of organic to aqueous phase, whether at high (5) or low (2) $\mathrm{pH}$, the extraction percentage increases with an equal slope. Therefore, it can be said that these two factors do not have an interaction on each other.

\section{Conclusions}

Based on previous studies, the most important factors affecting the solvent extraction of cerium were $\mathrm{pH}$, the concentration of extractant in the organic phase, and the ratio of organic to aqueous phase.

Optimum conditions for the solvent extraction of cerium from an aqueous solution using D2EHPA were: $\mathrm{pH}$ equal to 5, organic to aqueous phase ratio equal to 1 , and D2EHPA concentration equal to $0.08 \mathrm{~mol}$.

According to the results of this study, the designed experiments and their analysis by "Design Expert" software revealed that:

- by increasing the concentration of D2EHPA in the organic solution, the extraction percentage increased;

- by increasing the ratio of organic phase to the aqueous phase, the extraction percentage increased as well;

- by increasing $\mathrm{pH}$ of the solutions, the extraction percentage increased as well;

- the effect of extractant concentration was lower in higher ratios of organic to aqueous phase;

- concentration of D2EHPA and the ratio of organic to aqueous phase had an influence on each other;

- D2EHPA concentration and $\mathrm{pH}$ did not have a significant influence on each other;

- organic to aqueous phase ratio and $\mathrm{pH}$ did not have a significant influence on each other.

\section{Acknowledgments}

This study was funded by the Angouran Lead and Zinc Complex which included the purchase of all the raw material. Also, the data of conducted experiments were analyzed with the help of the Iranian Mines \& Mining Industries Development \& Renovation (IMIDRO). The authors would like to thank both organizations for their contribution.

\section{References}

[1] Xie F., Zhang T., Dreisinger D., Doyle F.: Miner. Eng., 2014, 56, 10. https://doi.org/10.1016/j.mineng.2013.10.021

[2] Gupta C., Krishnamurthy N.: Extractive Metallurgy of Rare Earths, CRC Press, Boca Raton 2005.

[3] Yin S., Wu W., Bian X. et al.: Int. J. Nonfer. Metallurgy, 2013, 2, 75. https://doi.org/10.4236/ijnm.2013.22010

[4] Desouky O.: Ph.D thesis, University of Leeds, Leeds, England 2006.

[5] Yin S., Wu W., Bian X., Zhang F.: Hydrometallururgy, 2013, 131, 133. https://doi.org/10.1016/j.hydromet.2012.11.005

[6] Wang X., Li W., Li D.: J. Rare Earths, 2011, 29, 413. https://doi.org/10.1016/S1002-0721(10)60470-X

[7] Nishihama S., Hirai T., Komasawa I.: J. Solid State Chem., 2003, 171, 101. https://doi.org/10.1016/S0022-4596(02)00198-6

[8] Luo X., Huang X., Zhu Z. et al.: J. Rare Earths, 2009, 27, 119. https://doi.org/10.1016/S1002-0721(08)60204-5

[9] Abhilash, Sinha S., Sinha M., Pandey B.: Int. J. Miner. Process., 2014, 127, 70. https://doi.org/10.1016/j.minpro.2013.12.009

[10] Liao W., Yu G., Li D.: Solvent Extr. Ion Exch., 2001, 19, 243. https://doi.org/10.1081/SEI-100102694

[11] Zhang D., Wang W., Deng Y. et al.: Chem. Eng. J., 2012, 179, 19. https://doi.org/10.1016/j.cej.2011.06.021

[12] Jun L., Zhenggui W., Deqian L. et al.: Hydrometallurgy, 1998, 50, 77. https://doi.org/10.1016/S0304-386X(98)00051-6

Received: August 10, 2016 / Revised: September 20, 2016 / Accepted: J anuary 20, 2017

\section{ДОСЛІДЖЕННЯ ВЗАСМОДІЇ ЕФЕКТИВНИХ ПАРАМЕТРІВ ВИЛУЧЕННЯ ЦЕРІЮ З СУЛЬФУРНОГО СЕРЕДОВИЩА З ВИКОРИСТАННЯМ ДИ-(2-ЕТИЛГЕКСИЛ) ФОСФАТНОЇ КИСЛОТИ}

Анотація. Досліджена екстракиія иеерію(III) з його сульфурного розчину з використанням ди-(2-етилгексил) фосфатної кислоти, розчиненої в гасі. Визначено чинники, які впливають на прочес екстракиії розчинником: концентрачія екстрагенту в органічній фазі, співвідномення органічної та водної фаз, температура, рН $i$ тривалість процесу. Встановлено, щзо температура $i$ тривалість прочесу мають менший вплив у порівнянні з іншими чинниками. Для всіх експериментів вибрано тривалість десять хвилин для двох фаз за кімнатної температури 298 К. Для планування експериментів, вивчення впливу чинників на екстракиію розчинником, статистичного аналізу та отримання оптимальних значень чинників застосовувалось програмне забезпечення "Design Expert”. Встановлено, щзо чинники, які впливають на екстракиію розчинником, за винятком конщентрачіï екстрагента $i$ співвідношення органічна фаза/ водна фаза, є незалежними і не мають ніякого взаємовпливу.

Ключові слова: иерій, планування експерименту, ди-(2етилгексил) фосфатної кислоти, екстракиія розчинником. 